UDC 008:712.01+9

Submitted: 01.07.2020

LBC 71+63.3(2)л6+85.118

Accepted: 20.07.2020

\title{
LANDSCAPE, MEMORY, HERITAGE AND IDENTITY (HISTORIOGRAPHICAL OVERVIEW)
}

\author{
Olga V. Galkova \\ Volgograd State Medical University, Volgograd, Russian Federation \\ Andrej V. Petrov \\ Volgograd State Medical University, Volgograd, Russian Federation \\ Viktor V. Glazunov \\ Volgograd State Medical University, Volgograd, Russian Federation
}

\begin{abstract}
Introduction. UNESCOs adoption of the Convention "Concerning the Protection of the World Cultural and Natural Heritage" of 1972 led to the discussion on the issues of mutual influence and interdependence of humankind and nature and human perception of the environment and his own ecological niche. As a result of these discussions, the term "cultural landscape" came into use, and became part of the world cultural heritage. Methods and materials. This study is based on the combination of the general, special historical and cultural methods. The central place among them was occupied by the comparative, analytical, historical-genetic, comparative analysis methods and some methods of historical cultural studies. Analysis. The evolution of the cultural landscape took place throughout human history and is a unique blend of not only human development. It also reflects, on the one hand, national culture and mentality, and on the other, shows the influence of natural factors on their development. It also helps to understand the mentality of various ethnic groups, similarities and differences in their perception of the world and attitude. The development of the cultural landscape concept has become an integral part of the Anthropocene theory, based on the teachings of V.I. Vernadsky, about the impact and intersection of the geo-, bio- and noosphere in the fate of humankind. Results. The article considers the development of the "cultural landscape" theory mainly in English and American historiography which conclusively demonstrates how natural factors impact on changes in culture of the same ethnos. Through historiographic studies and comparisons, it becomes possible to trace the importance of preserving and studying the cultural landscapes of the past and present, in order to understand ourselves and be responsible to the world around us.
\end{abstract} memory.

Key words: national identity, cultural heritage, rural landscape, historical and cultural monuments, historical

Citation. Galkova O.V., Petrov A.V., Glazunov V.V. Landscape, Memory, Heritage and Identity (Historiographical Overview). Vestnik Volgogradskogo gosudarstvennogo universiteta. Seriya 4. Istoriya. Regionovedenie. Mezhdunarodnye otnosheniya [Science Journal of Volgograd State University. History. Area Studies. International Relations], 2020, vol. 25, no. 5, pp. 247-257. (in Russian). DOI: https://doi.org/10.15688/jvolsu4.2020.5.20

УДК 008:712.01+9

Дата поступления статьи: 01.07.2020

ББК $71+63.3(2) л 6+85.118$

Дата принятия статьи: 20.07.2020

\section{ЛАНДШАФТ, ПАМЯТЬ, НАСЛЕДИЕ И ИДЕНТИЧНОСТЬ (ИСТОРИОГРАФИЧЕСКИЙ ОБЗОР)}

\section{Ольга Валентиновна Галкова}

Волгоградский государственный медицинский университет, г. Волгоград, Российская Федерация

\section{Андрей Владимирович Петров}

Волгоградский государственный медицинский университет, г. Волгоград, Российская Федерация 


\section{Виктор Владимирович Глазунов}

Волгоградский государственный медицинский университет, г. Волгоград, Российская Федерация

Аннотация. Введение. После принятия ЮНЕСКО конвенции 1972 г. «Об охране Всемирного культурного и природного наследия» в мировой исторической науке завязалась дискуссия по вопросам взаимовлияния и взаимозависимости природы и человека, восприятии человеком природной среды и создание и «обживании» им своей экологической ниши. В результате этих дискуссий появилось понятие «культурный ландшафт», которое стало частью всемирного культурного наследия. Анализ. Эволюция культурного ландшафта происходит на протяжении всей человеческой истории и является не только уникальным сплавом цивилизационного развития человечества, но и отражает, с одной стороны, национальную культуру и менталитет, а с другой - показывает влияние природных факторов на их развитие, что также помогает понять особенности менталитета различных этносов, общее и различное в их мировосприятии и мироощущении. Разработка понятия «культурный ландшафт» стала неотьемлемой частью теории антропоцена, основанной на учении В.И. Вернадского о взаимовлиянии и пересечении гео-, био- и ноосферы в судьбе человечества. Результа$m b l$ В данной статье авторы рассматривают развитие теории культурного ландшафта преимущественно в английской и американской историографии, где убедительно показывается, как влияют природные факторы на изменение культуры одного и того же по сути этноса. Через историографические исследования и их сравнения прослеживается важность сохранения и изучение культурных ландшафтов прошлого и современности для понимания человеком самого себя и ответственности человека перед окружающим его миром. Статья является результатом совместной работы авторов: О.В. Галковой была разработана концепция исследования, осуществлен подбор историографической литературы; В.В. Глазунов провел общий обзор и анализ памятников, входящих в состав исторических поселений; А.В. Петровым был осуществлен анализ философских концептов «памяти» и «идентичности».

Ключевые слова: национальная идентичность, культурное наследие, сельский ландшафт, памятники истории и культуры, историческая память.

Цитирование. Галкова О. В., Петров А. В., Глазунов В. В. Ландшафт, память, наследие и идентичность (историографический обзор) // Вестник Волгоградского государственного университета. Серия 4, История. Регионоведение. Международные отношения. - 2020. - Т. 25, № 5. - С. 247-257. - DOI: https://doi.org/10.15688/ jvolsu4.2020.5.20

Введение. Наметившийся в последние десятилетия рост интереса общества к окружающему его культурному и природному наследию стал проявляться в действиях, направленных на изучение, сохранение и рациональное использование как отдельных памятников истории и культуры, так и крупных территориальных комплексов - старых кварталов, исторических центров поселений, городских и сельских ландшафтов, составляющих в совокупности среду обитания человека. Процесс глобализации и стихийной урбанизации породил особый интерес целого ряда исследователей - прежде всего британских и американских ученых - к проблемам сохранения и изучения сельских культурных ландшафтов, выявлению связей сообществ с местами их обитания. Эти связи не только оказывают серьезное воздействие на формирование национальной и местной идентичности, но и порождают ценностное отношение человека к наследию, обществу и окружающему его пространству.
Методы и материалы. Исследование базируется на сочетании методов историографического исследования и исторической культурологии. Центральное место среди них заняли историко-генетический, компаративный, системный, семиотический, типологический и другие. Применение историко-генетического метода позволило проследить основные этапы развития теоретических представлений о культурном ландшафте как одном из видов наследия. Признавая ведущую роль ландшафта в формировании национальной и местной идентичности, в рамках данного исследования был проведен компаративный анализ концептуального содержания целого ряда историографических работ $[1 ; 2 ; 4 ; 6 ; 7 ; 10 ; 12 ; 14$; 18], что, в свою очередь, позволило прийти к выводу о необходимости сохранения и дальнейшего изучения данного вида наследия. Системный и типологический методы использовались для определения специфических особенностей и отличительных черт сельских культурных ландшафтов Англии и Америки, 
главным образом выражавшихся во влиянии на формирование местной и национальной идентичности.

Среди первых исследователей, сосредоточивших свое внимание на изучении проблем ландшафта, памяти, наследия и идентичности, оказались культурные и исторические географы. Начиная с 1990-х гг. в рамках данного направления были достигнуты определенные результаты $[9$, с. $294 ; 11$, с. $58 ; 28$, с. $327 ; 29$, c. 334]. Среди географов, исследовавших отношения между ландшафтом и национальной принадлежностью, наибольший интерес вызвали труды Стивена Дэниелса (Steven Daniels), Дэвида Ловенталя (David Lowenthal), Питера Бишопа (Peter Bishop), Дениса Косгроува (Denis Cosgrove), Дэвида Матлесса (David Matless) и Кэтрин Брэйс (Catherine Brace) [2; $3 ; 4 ; 5 ; 6 ; 14 ; 18]$.

Анализ. Одним из пионеров в этой области был Д. Ловенталь. Своими работами $[15$, с. $15-38 ; 17$, с. $104-105,183-184]$ на протяжении нескольких десятилетий ему удалось убедить англичан в том, чтобы они увидели свой ландшафт «не просто красивым или визуально особенным, но как восхитительным и наследственным» $[14$, с. 215].

Ловенталь видел значение английского ландшафта в том, что он в значительной степени определяется его связью с прошлым национального сообщества. Он полагал, что в этом отношении Англия выделяется среди других стран: «Нигде больше ландшафт не является таким нагруженным, как наследие» $[8$, c. 9]. Он подчеркивал, что для англичан традиционно привлекательными являются, прежде всего, сельские ландшафты: «Ландшафт, наиболее ценимый англичанами, в основном сельский по характеру. Это не пустыня дикой природы, ландшафт наводит на мысль о многовековом человеческом занятии и культивировании, и таким образом, о древности английской нации» [14, с. 216], причем «любимая сельская Англия втройне исторична. Его отличительными чертами являются компаунды датируемых культурных актов, в основном приписываемых предкам-предшественникам. Прошлое, которое пронизывает этот ландшафт, - это не первобытная дикая природа, а более близкая история, наполненная памятными человеческими процессами, желаниями, решениями и вкусами» $[14$, с. 216$]$. В связи с этим идея Гердера возвращения к природе и сельской местности, вдали от искусственности и коррупции города, получила наиболее сильный импульс в Англии и приняла отчетливо консервативные формы. Укорененный в сельской местности дискурс англичан был противопоставлен современности, превознося вместо этого пасторальную южную страну живописных коттеджей, мягко раскинувшихся сельскохозяйственных угодий и стабильных социальных иерархий, со сквайром и пастором наверху. Для англичан, богатых или бедных, сельских жителей или горожан, это был мираж, но он тем не менее предлагал соблазнительное видение мира и порядка, пронизывая английскую культуру и оказывая реальное влияние на все социальные группы общества.

Ловенталь (D. Lowenthal) и Принс (H.C. Prince) дали развернутую оценку взаимоотношениям англичан с окружающей средой. Подводя итог отношений между англичанами и их ландшафтом, они предложили слово «удобства» как ключевое понятие для обозначения почти всех видов интереса к месту и любой ее неотъемлемой ценности, которая выходит за рамки чисто экономических соображений. В одном городе «удобствами» являются исторические здания и аромат прошлого, в других открытые пространства, в третьих - взгляды и перспективы, в иных местах - объекты для отдыха или доступа к близлежащим живописным местам. Качество термина дает общественности чувство общего дела против тех, «для кого земля является лишь товаром» [16, с. 187].

В Америке девятнадцатого века народное отношение к вопросам наследия было совершенно иным, чем в Англии, и Ловенталь отметил, что первоначально нехватка человеческой истории в ландшафте опечалила, даже потрясла ранних колонистов, привыкших к реликтовым чертам Старого Света. С течением времени, однако, американский взор привык к иx tabula rasa. С революцией пришло понимание, что новизна не только терпима, а ей можно поклоняться, и отсутствие исторических остатков стало вопросом для самовосхваления.

В другом месте он отметил: «Сырая, незаконченная Америка встревожила чувствительные души, которые разделяют мнение мадам де Сталь, что «наиболее красивые пей- 
зажи в мире, если они не вызывают памяти, если они не имеют никаких следов каких-либо заметных событий, неинтересны по сравнению с историческими ландшафтами» [17, c. 114]. Разрывая узы империи, американские националисты считали, что они теряют имперскую страну и ее давние традиции. Американцы, которые таким образом отвернулись от истории человечества, отказались не только от романтической ностальгии, но и от полезного дополнения к национальной идентичности. Некоторые предупреждали, что игнорирование прошлого может испортить американский патриотизм. Другие, однако, нашли суррогаты для исторического наследия среди таких элементов, как природа, американские индейцы и классические прототипы [17, c. 101]. Пейзажи в достаточной степени компенсировали недостающие исторические ассоциации страны, а в первые десятилетия существования Республики поклонение природе достигло небывалых высот. Сравнивая английские и американские ландшафты, Ловенталь разъяснил и их различия в том влиянии, которое они оказывали на складывание идентичностей: «В исторических ландшафтах Европы было так много особенностей, что они были рассеянными и разнородными. Американские природные ландшафты, напротив, были едины, интегрированы и последовательны. И они внушали высокий порядок творчества» [17, с. 103]. И далее: «Обожествляя природу, американцы отвергали ближайшую перспективу для более отдаленного прошлого, рассматривая древность как вечность, а не как изменение. Они отказались от истории, чтобы принять предысторию. Первобытное качество американской природы использовалось снова и снова ... историческое прошлое было дегенеративным, тогда как первобытная природа была сильной, дикой, чистой и свободной» [17, c. 103-104]. Как только коренные американцы перестали представлять угрозу, они были приняты как символы древней уникальности и незафиксированного прошлого Америки, в то время как классические формы и герои древней Греции и Рима почитались в неисторических терминах и рассматривались как прототипы Американских добродетелей. Только после гражданской войны и столетия, когда индустриализация и массовая иммиграция из восточ- ной и южной Европы подогрели недовольство настоящим, американцы начали жаждать и романтизировать прошлое.

Ловенталь отмечал, что сегодняшнее прошлое - это накопление воспоминаний человечества, увиденных через перспективы нашего собственного поколения. То, что мы знаем об истории, отличается от того, что на самом деле произошло, не только потому, что доказательства прошлых событий были утеряны или подделаны, или потому, что задача просеивания их бесконечна, но также и потому, что изменяющийся образец постоянно требует новых интерпретаций того, что имело место [13, с. 103].

Он показал процесс постоянных изменений картин памяти в восприятии людей. Ловенталь подчеркнул, что каждый акт признания изменяет следы прошлого. Признание ценности реликвии или ее защита, не говоря уже о том, чтобы украсить ею или имитировать еe, влияет на их форму или наши впечатления. Так же, как избирательные воспоминания искажают память и формируют субъективное историческое понимание, манипулирование древностями преобразует их внешний вид и значение. Взаимодействие с наследием постоянно меняет его природу и контекст, по выбору или случайно [17, с. 236].

Мы воспринимаем прошлое через артефакты, физические следы и объекты в ландшафте, которые, как мы считаем, пережили «старые» времена. Вещи убеждают нас в их выживании двумя различными способами. Одним из них является их сходство или соответствие с формами, стилями или видами, которые являются историческим антиквариатом и устарели - отпечатки на открытом поле, винтажные автомобили, классические фронтоны. Этот способ восприятия можно назвать антикварным; это, по сути, гуманистический подход, требующий исторических знаний. Другой осознание длительного использования или износа - изношенный стул, сморщенное лицо, ржавая банка, покрытая плющом или плесенью стена. Этот подход, имеющий отношение к старению, по существу является натуралистическим, требующим понимания органических изменений [13, с. 108].

C. Шама (S. Schama) в своем исследовании «Пейзаж и память» писал, что унасле- 
дованные ландшафтные мифы и воспоминания имеют две общие характеристики: их удивительная устойчивость на протяжении веков и их сила формировать институты, которые мы до сих пор сохраняем. Национальная идентичность потеряла бы большую часть своего очарования без мистики определенной пейзажной традиции: ее топография нанесена на карту, разработана и обогащена как родная земля. Поэтическая традиция Ia douce France - «сладкая Франция» проявляется в том, что география описывает сладость классически упорядоченного места, где реки, возделанные поля, сады, виноградники и леса находятся в гармоническом равновесии друг с другом [22, с. 15].

При изучении запутанной английской национальной идентичности и ее связи с ландшафтом П.Дж. Тейлор (P.J. Taylor) определил территорию «Верхней Англии», доминирующую в национальном пространстве, округами, сгруппированными вокруг Лондона. Как выглядит эта верхняя Англия? С каким типом ландшафта англо-британцы идентифицируют себя? Ответы на эти вопросы приводят нас к парадоксу этого любопытного национализма. Пионер индустриализации и самая урбанизированная страна в мире идеализируют сельскую местность: соломенные коттеджи в окружении деревенской зелени являются частью типичной английской картины. Такие антиурбанистические образы сами по себе довольно распространены в национальных ландшафтах многих народов. Разница относительно англичан заключалась в том, что они не фигурировали в их собственном ландшафте $[26$, с. 151$]$. Тейлор указывал на эту особенность в формировании идентичностей как европейских народов, так и американцев. Сославшись на немецкого политического географа Фридриха Ратцеля, который утверждал, что каждая нация развивалась как симбиотическая ассоциация людей и земли, он справедливо подчеркнул, что в США государственность строилась аналогичным образом - на территории за пределами города, сначала на границе, а затем в «маленьких городках» Америки - месте целостности и правдивости, в отличие от «коррумпированных крупных городов». Вместе с тем, хотя все такие национальные образы, представляя общую природу людей, способствуют сельскому уклону в идентичности, они отражают только аспект этой реальности [26, с. 151].

В работе «Воображаемая страна» Дж.P. Шорт (J.R. Short) обратил внимание на то, что связь между ландшафтом и историей превращает ландшафт в наследие и вносит новое звучание в любую дискуссию, касающуюся использования и функций сельской местности. Идеологическая важность сельской местности означает, что она отделена от чисто сельскохозяйственных соображений. Он сформулировал причины высокой роли сельской местности в складывании национальной идентичности. Сельская местность - это больше, чем просто место, где фермеры выращивают урожай, разводят животных и зарабатывают деньги. Это место более широкого культурного значения и более глубокого идеологического значения, место, наполненное историческими ассоциациями, восприятием национальности и намеками на общину. Сельская местность стала местом более широкого политического значения, ландшафт власти - силой ландшафта, чтобы вызывать чувства и генерировать эмоции. Двумя важными причинами этого были доступность сельской местности и внешний вид деревни [24, с. 77$]$.

Дж.Р. Шорт повторил отождествление англичан с сельской иконой: сельская местность стала и остается самым важным ландшафтом в национальной экологической идеологии. Все это еще поддерживает гордость за родные пенаты. Он заметил, что в Англии существуют два значения страны - как сельской местности и как нации, которые переплетены друг с другом. Сущность Англии в народе ассоциируется с зеленой сельской местностью, полями, уединенными парковыми зонами загородных домов и небольших деревень. Шорт подчеркнул, что земельная элита девятнадцатого века, возможно, потеряла экономическую власть в двадцатом веке, но их символическая сила все еще очевидна. Сельская местность стала «настоящей» Англией, «неизменной» Англией, страной отступления от все более урбанизированного и все более индустриального общества, местом, где можно избежать современности [24, с. 75].

П. Шурмер-Смит (P. Shurmer-Smith) и К. Ханнам (K. Hannam) обратили внимание на 
то, что прошлое, раскрытое артефактами, историей и памятью, не совсем адекватно тому, что действительно происходило в прежние времена; скорее это в значительной степени искусственное прошлое, созданное человеческой забывчивостью и воображением. Тогда пластичное прошлое, созданное людьми, изучающими историю, может стать центром самобытности и убежищем от забот настоящего и будущего. Как объясняют П. ШурмерСмит и К. Ханнам, места в западном мире социально выстроены в соответствии с насыщенностью ностальгией, поскольку мы сознательно и неосознанно создаем и воссоздаем их с чувством истории.

История - это не только следы прошлого, но и результат диалога между многоголосым настоящим и прошлым. По мере того как мы делаем это, существует тенденция рассказывать одну историю как предшествующую, доминирующую историю, вокруг которой, предположительно, меньшие истории конкурируют, и именно эта доминирующая версия прошлого будет сохранена и представлена в физической форме, в образовании и тексте. То, что выживает в первозданном виде, восстанавливается или воссоздается в точной копии, возникает в определенных местах из воли людей, представляющих разные силы. Различные социальные группы стремятся к тому, чтобы их интерпретация прошлого была территориализована в текстах всех видов, включая ландшафты, «не по бескорыстным причинам, но чтобы помочь им получить то, что они хотят, или сохранить то, что у них есть», а именно доступ к экономическому и культурному капиталу [25, с. 45$]$.

Сохранение материальных фрагментов наследия является избирательным процессом. Предметы из прошлого выживают только там, где они ценятся современными обществами. Согласно Шурмер-Смит и Ханнам, средством, которым осуществляется переход от истории с низкой ценностью «старины» к истории с ее высокой ценностью, является процесс джентрификации [25, с. 54]. Сохранение или воссоздание ландшафтов представляет особые проблемы. Ряд таких проблем нашел отражение в работе Р. Мьюира «Долины Йоркшира». Например, в Великобритании широко поддерживается сохранение «нетронутой» сельской местности, но такие ландшафты редко являются творениями какой-либо отдельной исторической эпохи. Скорее, они представляют собой совокупности различных аспектов сельской местности, которые по разным причинам пережили разные периоды времени. Общественное беспокойство о сохранении также имеет тенденцию к избирательности с точки зрения того, что предназначено для сохранения. Сельская местность, известная ландшафтным историкам как «раннее вложение», пользуется большой популярностью. Она включает в себя как древние поля, так и земли, огороженные и «приватизированные», поскольку системы открытых полей были демонтированы в результате соглашений между членами деревенской общины. В обоих случаях это связано с ландшафтами небольших, неправильных полей, очерченных изогнутыми живыми изгородями (или заборами). Более многочисленны в английских центральных графствах во времена Чосера, Шекспира или Дефо были ландшафты открытого земледелия. Эти сельские местности характеризовались отсутствием разнообразия и мелких деталей, пахотными землями (гофрированными гребнями плуга, сходящимися в слегка изогнутые полосы земли), общими луговыми угодьями, заполняющими пространство между горизонтами. Там не было призывов к воссозданию и сохранению сельской местности, так как там был особый общественный порядок и удивительно запутанные системы немеханизированного земледелия, который никогда нельзя было восстановить. Как указывалось выше, за исключением тех, которые находятся в нескольких труднодоступных районах дикой природы, ландшафты являются культурными продуктами, поэтому их сохранение и поддержание касается сохранения культуры, а не сельской местности. В регионе, подобном Йоркшир-Дейлз становится ясно, что сохранение традиционных сельских местностей может быть достигнуто только путем искренней политики увековечивания небольших ферм и субсидирования мелкого фермера для поддержания традиционных черт ландшафта. Мелкий фермер сделал ЙоркширДейлс, и, когда он уходит, вместе с ним - и бесценные луга, пастбища, заборы и сараи. Странным образом это оказалось не беднос- 
тью, которая угрожает региону - жители долины справлялись с бедностью на протяжении веков - но богатство. Очаровательная красота, создаваемая бедными людьми из долин на протяжении веков, может быть разрушена богатыми чужими людьми в течение нескольких десятилетий [20, с. 218].

Общества, наделенные беспрецедентным уровнем ностальгии и заботящиеся о сохранении природы, сталкиваются со столь же беспрецедентной технологической способностью преобразовывать городские и сельские ландшафты таким образом, что стираются все ссылки на прошлое. Люди жаждут корней, и ландшафт обеспечивает фокус для личной и национальной идентичности. Но те ландшафты, которые больше всего напоминают о прошлом и о связях между общиной и землей, из-за малочисленности их подразделений и тонкости их исторических деталей представляют наибольшую угрозу для сил модернизации в сельской местности.

Однако исторические ассоциации мест не зафиксированы, что справедливо отметили Шурмер-Смит и Ханам: «Мифы об историческом месте... подвержены пересмотру. Значения места всегда радикально и тонко ретерриториализируются через переработку их прошлого» [25, с. 47].

Сколько бы усилий не было предпринято на сохранение наследия, предметы наследия, будь то каретный двор или сельская местность, являются продуктами обусловленного общественного порядка в определенном культурном, временном и пространственном контексте, которые невозможно воссоздать и сохранить. Стефан Миллс отмечал, что именно в восточных районах американцы разработали способы создания ландшафтов, которые были направлены на ликвидацию коренных народов в пользу основных сельскохозяйственных культур и отдаленной торговли. Как истоки республики лежат в восточном опыте, так и восточные ландшафтные преобразования лежат в основе развития американского ландшафтного опыта. И именно на востоке американцы сейчас находят «исторические ландшафты». Пытаясь найти истоки пограничных ландшафтов на востоке, американцы сталкиваются с проблемами, присущими презентации такого спорного прошлого в совре- менных ландшафтах: ландшафты колониального побережья были ориентированы на империализм, рабство и эксплуатацию окружающей среды. Но Томас Джефферсон превратил британский империализм в «Империю за свободу», где декадентские традиции не нашли своих корней $[19$, с. 106].

На наш взгляд, одной из самых необычных и интересных работ о роли ландшафта в формировании национальной и местной идентичности является сочинение Стивена Даниелса «Поля зрения: ландшафтный образ и национальная идентичность в Англии и Соединенных Штатах» [6]. В ней он отмечал, что ландшафтные образы - это не просто отражение или отвлечение внимания от более насущных социальных, экономических или политических проблем. Очень часто - это мощный способ познания и социального взаимодействия. Как образцы нравственного порядка и эстетической гармонии, отдельные ландшафты достигают статуса национальных икон. В этой книге Даниелс показал, как различные художники, ландшафтные дизайнеры и архитекторы формировали национальные идентичности в Англии и Соединенных Штатах с конца восемнадцатого века до наших дней. Автор обратил особое внимание на тех художников, которые находились в центре «дискуссии о наследии» и были представлены на выставках последнего десятилетия (таких как «Запад как Америка: переосмысление образов фронтира» в Национальном музее американского искусства). Анализ работ Кристофеpa Рена, Джона Констебля, Дж. Тернер, Томаса Коула, Хамфри Рептона, Джозефа Райта и Фрэнсиса Палмера позволил Даниелсу выяснить механизмы трансформации английских ландшафтных традиций в концепции американской национальной идентичности.

Исследование репрезентации сельских, городских и промышленных сцен в произведениях художников, писателей и дизайнеров позволило Даниелсу провести сравнительный анализ их интерпретаций в контексте их собственного времени и переосмысления в более поздние периоды.

Подчеркнув, что ландшафтные образы, инкапсулируя различные социальные отношения и формы знания, тем самым проявляют себя как изображения локальной, региональ- 
ной и национальной идентичности в ландшафте, Даниэлс раскрыл и обосновал связь между ландшафтным изображением и другим главным выражением национальной идентичности - историческим повествованием.

Появление постколониальных перспектив обратило внимание на вопросы деколонизации, диаспоры, расовой и этнической принадлежности, придавая тем самым импульс к решению более тонких и сложных вопросов, связанных с переплетением ландшафта, памяти и идентичности. Эта проблематика является главной для работ Д. Толи-Келли (D. ToliaKelly) о ландшафтных ценностях британских азиатов и Т. Джезила (T. Jazeel) о национализации природы в Шри-Ланке [10; 27]. Вместе с тем следует заметить, что работ, анализирующих постколониальную ситуацию, все же гораздо меньше исследований, посвященных изучению ландшафтов, расы и памяти $[1 ; 7$; 23]. Дж. Вайли полагает, что эти работы сами по себе стали почти что самостоятельным жанром [29, с. 182]. Многие из этих публикаций либо посвящены празднованиям годовщин знаменитых личностей, таких как Мартин Лютер Кинг [1], Артур Эш [12], либо - обсуждению спорных вопросов американской истории, например, Гражданской войны [7]. Оуэн Дуайер (O. Dwyer) наиболее четко провел идею о том, что ландшафтные памятники находятся не в статичном состоянии, а в процессе становления: вместо того чтобы иметь установленное фиксированное значение, памятники моментально воплощаются в сети изменяющихся социальных отношений. Все подобные работы подчеркивают и материальность ландшафтной организации, и символичность его значений, на основании чего ландшафт становится центром конфликтов, возникающих вокруг памяти, идентичности и справедливости.

В одной из последних работ, изданной в 2018 г., «Легендарная земля. Ландшафт и формирование национальной английской идентичности» профессор современной британской истории в лондонском Королевском колледже Пол Ридман (Paul Readman) показал связь процесса преобразования ландшафта в культурное наследие и конструирования современной коллективной идентичности.

Так же, как конкретный ландшафт может иметь особую ценность для отдельного человека из-за того, что он напоминает о событиях в прошлом этого человека (связано, например, со счастливым опытом в детстве), национальные общины приписывают ценность ландшафтам - воображаемое прошлое этих сообществ. Из-за его исторических ассоциаций ландшафт стал мощным средством, с помощью которого народ поддерживает чувство идентичности, и его полезность в этом отношении крепнет в контексте индустриализации, урбанизации, быстрых технологических и социальных изменений и других преобразований современности [21, с. 4].

С осознанием необходимости сохранения местного культурного наследия (до XVIII в.), а лишь затем (начиная с XVIII в.) - общенационального культурного достояния, он связывает и процесс формирования первоначально местной идентичности, а впоследствии - общенациональной: «До восемнадцатого века наследие, воплощенное в ландшафте, как правило, было связано с местными и конфессиональными идентичностями... Однако со временем это наследие стало считаться национальным по характеру, несмотря на сохранение ассоциаций между ландшафтом и местностью (которые, как мы увидим, не были противоположны новым языкам ландшафта и нации)» [21, с. 4].

Подчеркнув особую роль сельского ландшафта в формировании идентичности, он показал деятельность целого ряда общественных организаций, занимающихся сохранением сельского ландшафта и культуры, - Общество охраны общин, Национальный фонд, Общество сохранения Озерного края, Английское общество народной песни и танца. На основе анализа их взаимодействия с землей, ландшафтом и сельской местностью автор пришел к обоснованному выводу о том, что это взаимодействие «было центральным элементом английской культурной жизни» [21, с. 14]. В результате, в то время как большинство англичан и женщин жили в городах и поселках, с середины девятнадцатого века дискурсы сельской идентичности оставались неотъемлемой частью их опыта современности.

Вместе с тем автор показал противоречия в отношении к ландшафту в связи с проблемами в понимании патриотизма в общегосударственных масштабах и на местах, стол- 
кновением местных и общенациональной идентичностей. Исследуя ландшафт НьюФореста, Ридман проанализировал конфликт изза лесного массива в Нью-Форесте, находящегося на коронной земле и понимаемого с точки зрения национальных интересов как источник древесины, с одной стороны, а с другой-представление о лесе местных жителей как историческом культурном ландшафте.

Ридман обратил внимание на то, что, хотя в некоторых своих проявлениях эти сельские выражения английства, возможно, сознательно или неосознанно основанные на мифе, подавляя убожество, которое может скрываться в самых живописных розовых коттеджах, они тем не менее имели мощный эффект реального мира. Он подчеркнул, что их влияние было очевидно в ряде районов, что привело к сохранению ландшафтов и открытых пространств, появлению новых инициатив в области земельных и аграрных реформ, туризма и отдыха, изменению тенденции в искусстве и архитектуре и сочинениях о сельских ландшафтах и сельской жизни.

Вместе с тем автор справедливо отметил, что «сущностная Англия» может быть обнаружена не только в сельских районах Южной Англии, но и в других местах, как в городских, так и в сельских районах - от мрачных Вересковых пустошей Нортумбрии до удивительных и полностью искусственных ландшафтов промышленного Манчестера и его пригородов. Он заметил, что общими знаменателями, позволившими столь различным ландшафтам влиять на формирование идентичностей, были их ассоциативная ценность и чувство присутствия прошлого.

Подводя итог вышесказанному, Ридман выделил два главных фактора, определяющих влияние ландшафтов на складывание английской идентичности: во-первых, из-за их связи с английским прошлым, а во-вторых, из-за того, что он воспринимается как наследие, национальное достояние [21, с. 20].

Новым в работе было и то, что Ридман впервые проанализировал роль пограничных ландшафтов (например, на границе Англии и Шотландии) в формировании не только английской, но и британской идентичности.

Результаты. 1. Историографический обзор соотношения таких характеристик культурного ландшафта, как природа, память, памятник, история, позволяет сделать вывод, что ландшафтоведение является перспективным направлением в синтезе не только гуманитарного знания, но и естественнонаучного, являясь по своей сути трансдисциплинарным направлением в развитии познания мира.

2. Ландшафтоведение органически вписывается в такие перспективные научные направления, как «теория антропоцена» и «интеллектуальная история».

3. Изучение культурного ландшафта позволяет выявить его аксиологическую ценность не просто как памятника истории и культуры, но как историческое явление, влияющее на различия традиций, менталитета этносов, народов, наций, но подчас и на различия в менталитете отдельных социальных групп, что сегодня проявляется в различных культурных, социальных и политических доминантах.

\section{СПИСОК ЛИТЕРАТУРЫ}

1. Alderman, D. Street Names as Memorial Arenas: the Reputational Politics of Commemorating Martin Luther King Jr. in a Georgia County/D. Alderman // Historical Geography. - 2002. - Vol. 30. - P. 99-120.

2. Bishop, P. An Archetypal Constable: National Identity and the Geography of Nostalgia / P. Bishop.L. : Athlone, 1995. $-245 \mathrm{p}$.

3. Brace, C. Finding England Everywhere: Regional Identity and the Construction of National Identity, 1890-1940 / C. Brace // Ecumene. - 1998. Vol. 6, № 1. - P. 90-109.

4. Brace, C. Looking Back: the Cotswolds and English National Identity, 1890-1950 / C. Brace // Journal of Historical Geography. - 1999. - Vol. 25, № 1. - P. 502-516.

5. Cosgrove, D. The Iconography of Landscape: Essays on the Symbolic Representation, Design, and Use of Past Environments / D. Cosgrove, S. Daniels. Cambridge : Cambridge University Press, 1989. -330 p.

6. Daniels, S. Fields of Vision: Landscape Imagery and National Identity in England and the United States / S. Daniels. - Oxford: Princeton University Press, Polity Press and Blackwell, 1993. - $274 \mathrm{p}$.

7. Dwyer, O. J. Symbolic Accretion and Commemoration / O. J. Dwyer // Social and Cultural Geography. - 2004. - Vol. 5, № 3. - P. 419-435.

8. Fladmark, J. D. Heritage: Conservation, Interpretation and Enterprise / J. D. Fladmark, D. Lowenthal. - L. : Donhead, 1993. -355 p. 
9. Heffernan, M. For Ever England: the Western Front and the Politics of Remembrance in Britain / M. Heffernan // Ecumene (Cultural Geographies). - 1995. - Vol. 2. - P. 293-324. - DOI: https://doi.org/10.1177/147447409500200304.

10. Jazeel, T. Nature, Nationhood and the Poetics of Meaning in Ruhuna (Yala) National Park, Sri Lanka / T. Jazeel // Cultural Geographies. - 2005. - Vol. 12, № 2. - P. 199-228.

11. Johnson, N.C. Cast in Stone: Monuments, Geography, and Nationalism/N. C. Johnson//Environment and Planning D: Society and Space. - 1995. - Vol. 13.P. 51-65.

12. Leib, J. I. Separate Times, Shared Spaces: Arthur Ashe, Monument Avenue, and the Politics of Richmond, Virginias Symbolic Landscape / J. I. Leib // Cultural Geographies. -2002. - Vol. 9. -P. 286-312.

13. Lowenthal, D. Age and Artifact / D. Lowenthal, D. W. Meinig. - Oxford : Oxford University Press, 1979.$255 \mathrm{p}$.

14. Lowenthal, D. British National Identity and the English Landscape / D. Lowenthal // Rural History. 1991. - Vol. 2, № 2. - P. 205-230.

15. Lowenthal, D. European and English Landscapes and National Symbols / D. Lowenthal. Hoboken : Blackwell Publishers, 1994.-404 p.

16. Lowenthal, D. The English Landscape / D. Lowenthal, H. Prince // Geographical Review. 1964. - Vol. 54, № 3. - P. 186-222.

17. Lowenthal, D. The Past is a Foreign Country / D. Lowenthal. - Cambridge : Cambridge University Press, 2015. $-680 \mathrm{p}$.

18. Matless, D. Landscape and Englishness / D. Matless. - L. : Reaktion Books, 2001. - 367 p.

19. Mills, S. F. TheAmerican Landscape/S. F. Mills. Edinburgh : Keele University Press, 1997.-160p.

20. Muir, R. The Dales of Yorkshire / R. Muir. L. : Macmillan, 1991. - 229 p.

21. Readman, P. Storied Ground. Landscape and the Shaping of English National identity / P. Readman. Cambridge : Cambridge University Press, 1998. - 348 p.

22. Schama, S. Landscape and Memory/S. Schama. L. : Harper Collins, 1995. -672p.

23. Schein, R. Landscape and Race in the United States / R. Schein. - N. Y. : Routledge, 2006. - 272 p.

24. Short, J. R. Imagined Country/J. R. Short. L. : Routledge, 1991. - 254 p.

25. Shurmer-Smith, P. Worlds of Desire, Realms of Power: A Cultural Geography / P. Shurmer-Smith, K. Hannam. - L. : Edward Arnold, 1994. - 256 p. -DOI: https://doi.org/10.1111/j.1745-7939.1997.tb00504.x.

26. Taylor, P. J. The English and Their Englishness: «A Curiously Mysterious, Elusive and Little Understood People» / P. J. Taylor // Scottish Geographical Magazine. - 1991. - Vol. 107, № 3. P. 146-161.
27. Tolia-Kelly, D. Landscape, Race and Memory: Biographical Mapping of the Routes of British Asian Landscape Values / D. Tolia-Kelly // Landscape Research. - 2004. - Vol. 29. - P. 277-292.

28. Withers, C. Place, Memory, Monument: Memorializing the Past in Contemporary Scotland / C. Withers // Ecumene. - 1996. - Vol. 3, № 3. P. $325-344$.

29. Wylie, J. W. Landscape / J. W. Wylie. - L. : Routlage, 2007.-252 p.

\section{REFERENCES}

1. Alderman D. Street Names as Memorial Arenas:The Reputational Politics of Commemorating Martin Luther King Jr. in a Georgia County. Historical Geography, 2002, vol. 30, pp. 99-120.

2. Bishop P. An Archetypal Constable: National Identity and the Geography of Nostalgia. London, Athlone, 1995. $245 \mathrm{p}$.

3. Brace C. Finding England Everywhere: Regional Identity and the Construction of National Identity, 1890 1940. Ecumene, 1998, vol. 6, no. 1, pp. 90-109.

4. Brace C. Looking Back: The Cotswolds and English National Identity, 1890-1950. Journal of Historical Geography, 1999, vol. 25, no. 1, pp. 502-516.

5. Cosgrove D. The Iconography of Landscape: Essays on the Symbolic Representation, Design, and Use of Past Environments. Cambridge, Cambridge University Press, $1989.330 \mathrm{p}$.

6. Daniels S. Fields of Vision: Landscape Imagery and National Identity in England and the United States. Oxford, Princeton University Press, Polity Press and Blackwell, 1993. 274 p.

7. Dwyer O.J. Symbolic Accretion and Commemoration. Social and Cultural Geography, 2004, vol. 5, no. 3, pp. 419-435.

8. Fladmark J.D. Heritage: Conservation, Interpretation and Enterprise. London, Donhead, $1993.355 \mathrm{p}$.

9. Heffernan M. For Ever England: The Western Front and the Politics of Remembrance in Britain. Ecumene (Cultural Geographies), 1995, vol. 2, pp. 293324. DOI: https://doi.org/10.1177/147447409500200304.

10. Jazeel T. Nature, Nationhood and the Poetics of Meaning in Ruhuna (Yala) National Park, Sri Lanka. Cultural Geographies, 2005, vol. 12, no. 2, pp. 199-228.

11. Johnson N.C. Cast in Stone: Monuments, Geography, and Nationalism. Environment and Planning, Society and Space, 1995, vol. 13, pp. 51-65.

12. Leib J.I. Separate Times, Shared Spaces: Arthur Ashe, Monument Avenue, and the Politics of Richmond, Virginias Symbolic Landscape. Cultural Geographies, 2002, vol. 9, pp. 286-312. 
13. Lowenthal D. Age and Artifact. The Interpretation of Ordinary Landscapes. Oxford, Oxford University Press, 1979. 255 p.

14. Lowenthal D. British National Identity and the English Landscape. Rural History, 1991, vol. 2, no. 2, pp. 205-230.

15. Lowenthal D. European and English Landscapes and National Symbols. Hoboken, Blackwell Publishers, 1994. 404 p.

16. Lowenthal D. The English Landscape. Geographical Review, 1964, vol. 54, no. 3, pp. 186-222.

17. Lowenthal D. The Past is a Foreign Country. Cambridge, Cambridge University Press Publ., 2015. $680 \mathrm{p}$.

18. Matless D. Landscape and Englishness. London, Reaktion Books, 2001.367 p.

19. Mills S.F. The American Landscape. Edinburgh, Keele University Press, 1997. 160 p.

20. Muir R. The Dales of Yorkshire. London, Macmillan, 1991.229p.

21. Readman P. Storied Ground. Landscape and the Shaping of English National Identity. Cambridge, Cambridge University Press, 1998. 348 p.
22. Schama S. Landscape and Memory. London, Harper Collins, 1995. 672 p.

23. Schein R. Landscape and Race in the United States. New York, Routledge, 2006. 272 p.

24. Short J.R. Imagined Country. London, Routledge, $1991.254 \mathrm{p}$.

25. Shurmer-Smith P. Worlds of Desire, Realms of Power: A Cultural Geography. London, Edward Arnold, 1994.256 p. DOI: https://doi.org/10.1111/j.17457939.1997.tb00504.x.

26. Taylor P.J. The English and Their Englishness: «A Curiously Mysterious, Elusive and Little Understood People». Scottish Geographical Magazine, 1991, vol. 107, no. 3, pp. 146-161.

27. Tolia-Kelly D. Landscape, Race and Memory: Biographical Mapping of the Routes of British Asian Landscape Values. Landscape Research, 2004, vol. 29, pp. 277-292.

28. Withers C. Place, Memory, Monument: Memorializing the Past in Contemporary Scotland. Ecumene, 1996, vol. 3, no. 3, pp. 325-344.

29. Wylie J.W. Landscape. London, Routlage, 2007.252 p.

\section{Information About the Authors}

Olga V. Galkova, Doctor of Sciences (History), Professor, Department of History and Cultural Studies, Volgograd State Medical University, Pavshikh Bortsov Sq., 1, 400131 Volgograd, Russian Federation, galkolia@mail.ru, https://orcid.org/0000-0001-8524-5709

Andrej V. Petrov, Doctor of Sciences (Philosophy), Professor, Department of the Philosophy, Bioethics and Law with the Course of Psychology and Sociology for Medicine, Volgograd State Medical University, Pavshikh Bortsov Sq., 1, 400131 Volgograd, Russian Federation, avpetrov79@mail.ru, https://orcid.org/0000-0003-0157-5554

Viktor V. Glazunov, Candidate of Sciences (History), Associate Professor, Department of History and Cultural Studies, Volgograd State Medical University, Pavshikh Bortsov Sq., 1, 400131 Volgograd, Russian Federation, glazunov088@gmail.com, https://orcid.org/0000-0002-2576-7561

\section{Информация об авторах}

Ольга Валентиновна Галкова, доктор исторических наук, профессор кафедры истории и культурологии, Волгоградский государственный медицинский университет, пл. Павших Борцов, 1, 400131 г. Волгоград, Российская Федерация, galkolia@mail.ru, https:/orcid.org/0000-0001-8524-5709

Андрей Владимирович Петров, доктор философских наук, профессор кафедры философии, биоэтики и права с курсом социологии медицины, Волгоградский государственный медицинский университет, пл. Павших Борцов, 1, 400131 г. Волгоград, Российская Федерация, avpetrov79@mail.ru, http://orcid.org/0000-0003-0157-5554

Виктор Владимирович Глазунов, кандидат исторических наук, доцент кафедры истории и культурологии, Волгоградский государственный медицинский университет, пл. Павших Борцов, 1, 400131 г. Волгоград, Российская Федерация, glazunov088@gmail.com, https://orcid.org/0000-0002-2576-7561 